AperTO - Archivio Istituzionale Open Access dell'Università di Torino

\title{
Diversifying in Public Real Estate: the Ex-Post Performance
}

\section{This is a pre print version of the following article:}

Original Citation:

\section{Availability:}

This version is available http://hdl.handle.net/2318/22809

Publisher:

London (Museum House, 25 Museum St., London, WC1A 1JT) : Henry Stewart, 2000-

Published version:

DOI:10.1057/palgrave.jam.2250089

Terms of use:

Open Access

Anyone can freely access the full text of works made available as "Open Access". Works made available under a Creative Commons license can be used according to the terms and conditions of said license. Use of all other works requires consent of the right holder (author or publisher) if not exempted from copyright protection by the applicable law. 


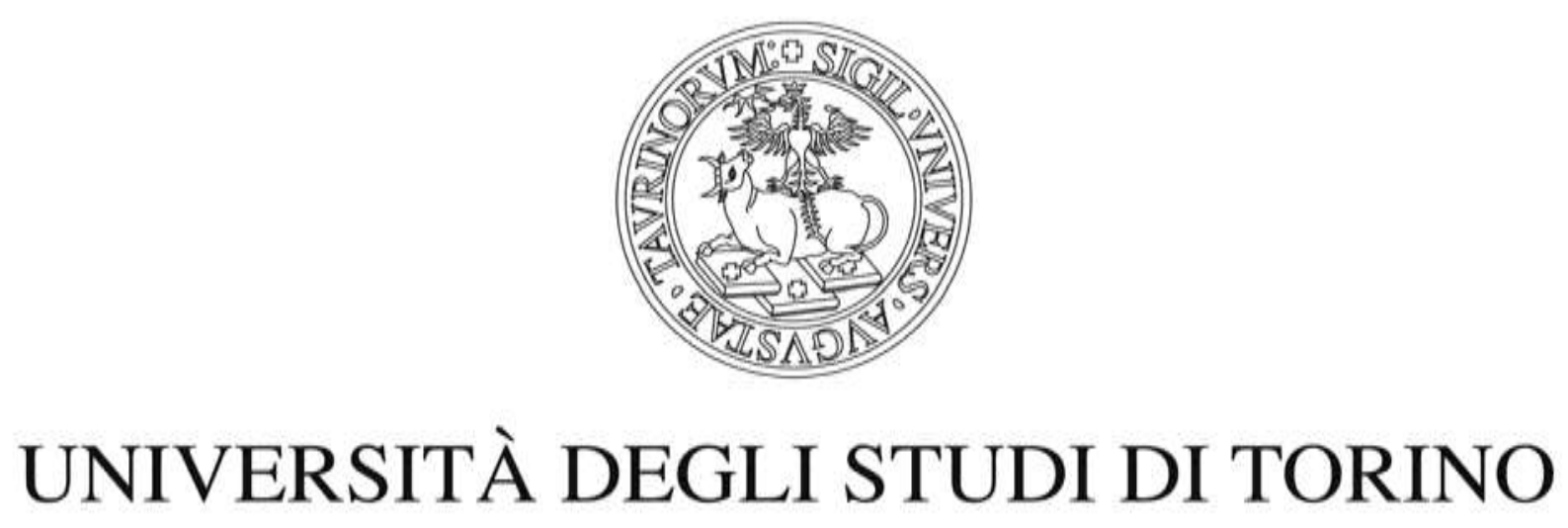

This is an author version Pre-Print of the contribution published on:

Journal of Asset Management, Vol.8(6), 2008, p.361-373

DOI: http:// 10.1057/palgrave.jam.2250089

The definitive version is available at:

http://www.palgrave-journals.com/jam/journal/v8/n6/full/2250089a.html 


\title{
Diversifying in Public Real Estate: the Ex-Post Performance
}

\author{
Carolina FUGAZZA \\ CERP-Collegio Carlo Alberto (CeRP-CCA) and University of Turin \\ Massimo GUIDOLIN** \\ CERP-CCA, Manchester Business School, and Federal Reserve Bank of St. Louis \\ Giovanna NICODANO* \\ CERP-CCA and University of Turin
}

This draft: August 2007

\begin{abstract}
We calculate the ex-post portfolio performance for an investor who diversifies among stocks, bonds, REITS and cash. Simulations are performed for two alternative asset allocation frameworks - classical and Bayesian - and for scenarios involving two different samples and six different investment horizons. Interestingly, the ex-post welfare cost of restricting portfolio choices to traditional financial assets only is found to be positive in all scenarios for a Bayesian investor. On the contrary, substitution of E-REITS for stocks in optimal portfolios turns out to reduce ex-post portfolio performance over the nineties for a Classical investor.
\end{abstract}

JEL Classification Codes: G11, L85.

Keywords: optimal asset allocation, real estate, parameter uncertainty, out-of-sample performance.

* Collegio Carlo Alberto, Via Real Collegio 30, Moncalieri (Torino), 39(011)6705040 - fax 5042 giovanna.nicodano@unito.it 
Several papers argue that the diversification gains from enlarging the asset menu to securitized real estate are large, given its imperfect correlation with traditional assets. ${ }^{1}$ These studies usually consider the in-sample, ex-ante performance of optimal portfolios, and are therefore retrospective in nature. However, the inclusion of any asset can only increase the ratio of expected return to volatility of the optimal portfolio. This is an implication of the mean variance model, and is true - ex-ante - for any additional asset that is less than perfectly correlated with the existing ones. Ex-post, an additional asset may actually worsen portfolio performance. For instance, the risk return trade-off may happen to be worse over the out-of-sample period than in the sample used for ex-ante calculations. This may happen in a single (out-of) sample of finite length because of the occurrence of large negative shocks to returns -i.e., bad luck. Alternatively, the model used to estimate expected returns and volatilities may be ill-specified and therefore break down when tested out-of-sample.

Against this background, this paper assesses the ex-post gains accruing to risk-averse investors deriving from the inclusion of US real estate vehicles (REITS) in portfolios composed of US stocks, bonds and cash. Such gains are averaged over 120 portfolio allocations, and are computed with the following recursive estimation and portfolio selection scheme. We first use data from January 1972 up to December 1994 to estimate and forecast means, variances, and covariances of returns on all asset classes and solve for optimal portfolio weights. This exercise is repeated the following month, using data up to January 1995 to compute afresh forecasts of return moments and select portfolio weights. Iterating this recursive scheme until the end of our sample (November 2004) generates a sequence of 120 realized portfolio returns from which Sharpe ratios, realized utility, and certainty equivalent returns of optimal portfolios are computed. Our evaluation of the role of real estate thus averages times of good and bad

\footnotetext{
${ }^{1}$ See Seiler, Webb and Myer [1999] and Feldman [2003], among others, the imperfect correlation with other assets. This view is not shared by Giorgiev, Gupta and Kunkel [2003], who find negligible increases in Sharpe ratios over the period 1990-2002.
} 
performance for this asset class.

It is well known that parameter estimation errors affect the ex-post performance of mean-variance portfolios [Bawa, Brown and Klein [1979], Jobson, Korkie and Ratti [1979] and Jorion, [1985]]. Typically, optimal portfolio shares are too sensitive to small changes in expected return forecasts, because the coefficients entering the (conditional) mean function are considered as fixed parameters in classical estimation methods. In order to cope with this problem, portfolio managers adopt well established robust estimation methods for expected returns, such as shrinkage and Bayesian estimators, that are known to improve on classical mean variance out-of-sample outcomes. In this paper we also use a Bayesian approach to account for parameter uncertainty. Rather than focussing on expected returns alone, we obtain the predictive density of future asset returns that accounts for uncertainty surrounding all moments of the cumulative return distribution of portfolios, as in Barberis [2000]. Such distribution is typically not normal, even when one period returns on each individual asset class are normally distributed. ${ }^{2}$ The number of portfolio allocations and associated realized returns for our out-of-sample assessment therefore climb up to 240 , since the recursive scheme is applied twice, the first time to a Classical investor, the second to a Bayesian problem.

Parameter uncertainty may also give rise to horizon effects [Barberis, 2000]. For instance, longer-horizons investors may pick less stocks and more cash than shorter horizon ones when they choose between these two assets only. We calculate optimal portfolio shares for buy-and-hold investors with different horizons, namely 1, 3, 6, 12, 24 and 60 months. We are thus able to check whether such horizon effects hold when the asset menu includes bonds and real estate as well. Enlarging our analysis along these lines implies checking for the ex-post performance of a sequence of 240 recursive portfolios for six different holding periods, for a total of 1,440 allocations. Therefore, ours is a rather massive effort

\footnotetext{
${ }^{2}$ This approach nicely extends to the case of predictable returns when model uncertainty is also present [Avramov, 2002].
} 
devoted to the understanding of whether and why publicly traded real estate may improve the ex-post portfolio performance when mixed to traditional financial assets. Moreover, by focussing on long-run objectives, our analysis becomes relevant not only to mutual funds but also to other institutional investors, such as pension funds, with longer investment horizons. ${ }^{3}$

We find that ex-post gains from including securitized real estate are always large, provided that the investors accounts for parameter uncertainty. The Sharpe ratio increases by at least $17 \%$ per month, as a consequence of the introduction of real estate. Such large gains for the Bayesian investor obtain due to higher mean portfolio returns that dominate mildly larger realized volatilities. These gains fail to show an obvious pattern across investment horizons. Thus, considering REITS as an additional asset is equally valuable for both short and long term Bayesian investors.

It is well known that the Sharpe ratio can be a misleading indicator of performance when returns are not normally distributed [Leland, 1999, Goetzman et al., 2002, 2004]. In our paper, log returns on individual assets are assumed to be normally distributed; however the resulting, optimal portfolio returns are not. Thus, we also study the welfare gains deriving from real estate. Specifically, we measure the annualized percentage increase in initial wealth that should be awarded to a Bayesian investor in order to compensate her for excluding REITS from her asset menu. Such measure ranges from 0.84 to 1.68 percent of initial wealth, confirming results obtained with the Sharpe ratio.

Availability of real estate vehicles induces more risk taking also for a Classical investor, who overlooks parameter uncertainty. However such enhanced risk taking is not rewarded ex-post (by realized returns and portfolio moments) in our sample, given that the benchmark portfolio with no real estate is already very risky. The ex-post Sharpe ratio, when the asset menu includes securitized real estate, turns out to be lower than in the benchmark case without real estate, and for all investment horizons.

\footnotetext{
${ }^{3}$ In a similar vein, Geltner and Rodriguez [1995] compute mean-variance portfolios on the basis of 5-year return statistics.
} 
The textbook advice for estimating inputs for optimal portfolio allocation is to use 5 years of monthly data. We thus check the robustness of our results when initial estimates are obtained using data over the period 1972-1976 only. This exercise is also interesting because mean returns for REITS are lower than those on T-Bills and T-Bonds over this period, whilst REITS were top performers over 1972-1994. Thus, in this case the benchmark, no-real estate allocation for the Classical investor is overwhelmingly invested in cash. When real estate is added, risk taking is enhanced and this translates in improved ex-post performance for a Classical investor as well. Results for the Bayesian investor are confirmed, in that gains in both Sharpe ratios and welfare remain substantial.

Our analysis complements the study by Ling et al. (2000), who also emphasize out-of-sample performance of investments in REITs. They focus on the differential returns of active versus buy-and-hold strategies, and find that they are negligible once transaction costs are accounted for. Here, we focus on the out of sample contribution of REITs to buy-and-hold, diversified portfolios, which is consistent with ignoring transaction costs.

The plan of the paper is as follows. The following section briefly outlines the methodology of the paper. We then describe the data and their statistical properties. In the core section of the paper, we characterize optimal portfolios including real estate, and compare them to the case without real estate. The last section concludes. An Appendix collects details on the statistical models and solution methods employed in the paper.

\section{Asset Allocation Models}

Consider an investor who maximizes expected utility from terminal wealth by choosing optimal portfolio weights $\left(\gamma_{t}\right)$, when preferences are described by a power utility function:

$$
\max _{\omega_{t}} E_{t}\left[\frac{W_{t+T}^{1-\gamma}}{1-\gamma}\right] \quad \gamma>1,
$$

where $T$ indicates the planning horizon and $\Lambda$ is the coefficient of constant relative risk aversion. Wealth 
can be invested in four risky asset classes: stocks, bonds, real estate and cash. The continuously compounded excess returns between month $t-1$ and $t$ are respectively denoted by $r_{t}^{s}, r_{t}^{b}$, and $r_{t}^{r}$, while $r_{t}^{f}$ is the return on cash. ${ }^{4}$ The fraction of wealth invested in stocks, in bonds, and in real estate are $V_{p}$,

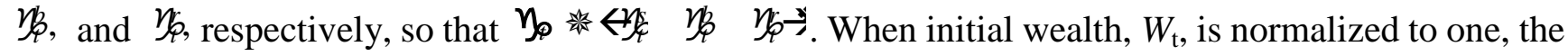
investor's terminal wealth is given by:

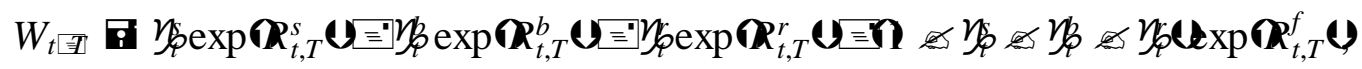

where $R_{t, T}^{s}, R_{t, T}^{b}, R_{t, T}^{r}$, and $R_{t, T}^{f}$ denote the cumulative returns between $t$ and $T$ :

$$
R_{t, T}^{i} \equiv \sum_{k=1}^{T}\left(r_{t+k}^{i}+r_{t+k}^{f}\right) i=s, b, r ; R_{t, T}^{f} \equiv \sum_{k=1}^{T}\left(r_{t+k}^{f}\right)
$$

The buy-and-hold problem, when short-sales constraints are imposed, is: ${ }^{5}$

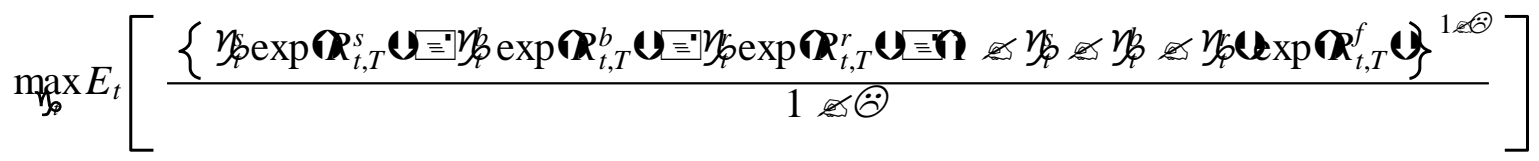

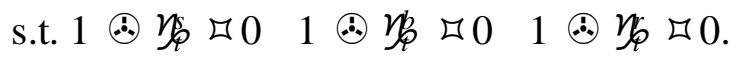

The vector of (excess) returns is assumed to be multivariate Gaussian:

$$
\mathbf{z}_{t}=\boldsymbol{\mu}+\boldsymbol{\varepsilon}_{t},
$$

where $\mathrm{O}_{\mathrm{t}}$ is i.i.d. $N(\mathbf{0}, \boldsymbol{\Sigma})$.

In computing optimal portfolios, the investor may consider classical estimates of the coefficients characterizing the return generating process as corresponding to true parameters. This is a classical approach. Alternatively, the investor takes into account the uncertainty surrounding the coefficients, and calculates conditional moments employing the predictive density of future asset returns. This is a

\footnotetext{
${ }^{4}$ The notation $r_{t}^{f}$ is meant to signal that on the interval $[t-1, t]$ a short-term deposit investment is free of risk.

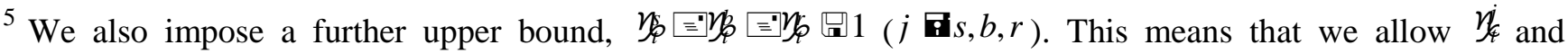

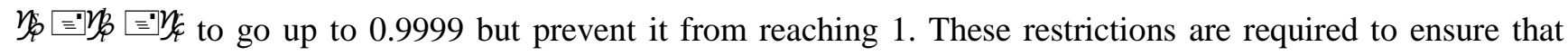
expected utility is defined when solving the portfolio problem.
} 
Bayesian approach. In the following we distinguish between these two different asset allocation frameworks.

\section{Classical Portfolio Choice}

The problem can be solved by employing simulation methods similar to Kandel and Stambaugh (1996), Barberis (2000), and Guidolin and Timmermann (2005), discussed in the Appendix. These entail the maximization of

$$
\max _{\omega_{t}} \frac{1}{N} \sum_{i=1}^{N}\left[\frac{\left\{\omega_{t}^{s} \exp \left(R_{t, T}^{s, i}\right)+\omega_{t}^{b} \exp \left(R_{t, T}^{b, i}\right)+\omega_{t}^{r} \exp \left(R_{t, T}^{r, i}\right)+\left(1-\omega_{t}^{s}-\omega_{t}^{b}-\omega_{t}^{r}\right) \exp \left(R_{t, T}^{f, i}\right)\right\}^{1-\gamma}}{1-\gamma}\right]
$$

where $N$ is the number of draws from the conditional distribution of future asset returns and $\leftrightarrow_{t, T}^{s, i} R_{t, T}^{b, i}$ $R_{t, T}^{r, i} R_{t, T}^{f, i}$ are the elements of $\mathbf{z}_{t, T}^{i}$ along a sample path $i=1,2, \ldots, N$. In the results that follow, we employ $N=30,000$ Monte Carlo trials in order to minimize any residual random errors in optimal weights induced by simulations.

\section{Bayesian Portfolio Choice}

Since the true values of the coefficients are unknown, the uncertainty induced by estimation risk may substantially affect portfolio rules. Call $\Sigma$ the vector collecting all unknown coefficients characterizing means, variances, and covariances in the statistical model in (5). Parameter uncertainty is incorporated in the model by using a Bayesian framework that relies on the principle that portfolio choices ought to be based on the multivariate predictive distribution of future asset returns. Such a predictive distribution is obtained by integrating the joint distribution of $\Sigma$ and returns $p \mathbf{\mathbf { z }}_{t, T}, \mathbf{c} \mathbf{Z}_{t} \iota_{\text {with }}$ respect to the posterior distribution of $\Sigma, p \mathbf{r} \mathbf{z} \mathbf{Z}_{t}$ :

\section{$p \mathbf{\mathbf { z }}_{t, T} \cup \overline{\mathbf{T}}$}

where $\mathbf{Z}_{t}$ collects the time series of observed values for asset returns and the predictor, $\mathbf{Z}_{t} \mathbf{z}_{i} \Downarrow_{i \mathbf{a}}$. 
When parameter uncertainty is taken into account, the maximization problem becomes:

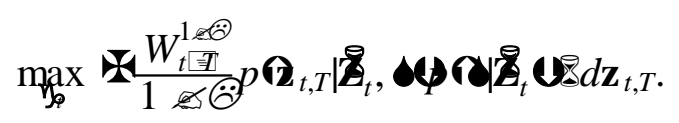

In this case, Monte Carlo methods require drawing a large number of times from $p \mathbf{\mathbf { Q }}_{t, T} \ell$ and then "extracting" cumulative returns from the resulting vector.

The Appendix provides further details on the solution methods and on the Bayesian prior densities, which we simply assume to be of a standard uninformative diffuse type, as in Barberis [2000]. In particular, since applying Monte Carlo methods implies a double simulation scheme, in the following $N$ is set to a relatively large value of 30,000 independent trials that are intended to approximate the joint predictive density of excess returns and predictors.

\section{Estimation Results}

\section{Data and Descriptive Statistics}

Our sample of monthly data runs from January 1972 to November 2004 for a total of 371 observations, as the US public real estate data we use are available for this time span only. The sample period is well-balanced, including several, complete bull and bear stock market cycles. The NaREIT website provides monthly returns on equity REITS. ${ }^{6}$ Stock returns are derived from the value weighted CRSP index of listings on the NYSE, NASDAQ and the AMEX. The 10-Year constant maturity portfolio

returns on Treasury Bonds as well as the 1-month T-bill come from the Federal Reserve Bank of St. Louis database $\left(\right.$ FREDII $\left.^{\circledR}\right)$.

We use continuously compounded total return market-capitalization indices, including both capital gains and income return components. Excess returns are calculated by deducting short-term cash returns from 
total returns. The short-term investment yield is expressed in real terms as the difference between the nominal yield and the seasonally-adjusted monthly rate of change in the consumer price index for urban consumers provided by FREDII ${ }^{\circledR}$.

In Exhibit 1 we present summary statistics. Over our complete sample period, the US securitized real estate market dominates (in mean-variance terms) the stock market, in spite of the euphoria characterizing the years from 1995 to 2000: real estate investments perform better than equities in mean terms ( 0.5 and 0.3 percent per month in excess of short-term deposits, respectively), and are less volatile than stocks (their monthly standard deviation is $4 \%$ vs. $4.6 \%$ for equities). In annualized terms, these correspond to means and volatilities of 4.0 and $16.1 \%$ for stocks and 6.0 and $13.8 \%$ for E-REITs. As one would expect, bonds have been less profitable $(0.1 \%)$ but also less volatile $(2.3 \%)$ than stocks and real estate. Correspondingly, the Sharpe ratio of real estate almost doubles (0.13) the equity ratio (0.07).

The right-hand side column provides simultaneous correlations. Performance of the four assets is only weakly correlated, with a peak correlation coefficient of 0.570 between excess stock and real estate returns. Under these conditions, there is wide scope for portfolio diversification across assets. Excess bond returns are characterized by correlations vs. both stock and real estate lower than 0.2 . Even lower is the correlation of the real return on T-Bills with stocks and E-REITs, which never exceeds 0.12: therefore we expect a relatively large demand for T-Bills for hedging purposes.

The middle and bottom panels report the same descriptive statistics for the two sub-samples used for initial parameter estimation in our recursive experiments. The sub-sample 1972-1994 is qualitatively similar to the full sample, although investment opportunities worsen: Sharpe ratios are lower and all correlations increase. On the opposite, the years 1972-1976 are quite different, being characterized by the 1973 oil shock and subsequent world-wide recession: Sharpe ratios for both stocks and E-REITs turn

\footnotetext{
${ }^{6}$ It covers all real estate investment trusts that are listed on the New York Stock Exchange, the American Stock Exchange or the NASDAQ National Market List. Only trusts that satisfy a minimum capitalization and turnover
} 
negative, although correlations remain largely unchanged. In the next section we assess how these differences in the data used to estimate initial parameters affect optimal portfolio shares.

\section{Optimal Asset Allocation with Real Estate}

Portfolio composition changes depending on perceived market conditions as information arrives. One way to approach this problem involves estimating a range of optimal portfolio shares through Monte Carlo simulation of returns as in Ziobrowski, Caines and Ziobrowski [1999]. Instead we compute averages of optimal portfolios for investors entering the market at different dates.

Exhibit 2 reports such average weights for horizons between 1 and 60 months. The investor is assumed to have an intermediate coefficient of relative risk aversion, $\Lambda=5$, a typical value in the empirical portfolio choice literature. $^{7}$

We start by considering a Classical investor who commits her initial wealth for $T$ months and ignores parameter uncertainty. Over the sample 1995-2004, we find that portfolio weights with real estate are extremely different than those obtained under a no-real estate benchmark. For instance, the average percentage to be invested in stocks for a one month horizon are $13 \%$ with real estate vs. $40 \%$ without real estate, $22 \%$ vs. $25 \%$ for long-term bonds, and 16 vs. $36 \%$ for T-Bills. Real estate vehicles attract a sizeable weight of $49 \%$ of the overall portfolio, thus reducing the appeal of stocks and T-Bill, the combined weight of which declines by $47 \%$ when real estate is introduced. A portfolio share of $49 \%$ on E-REITs is very high, compared to the typical findings in literature. ${ }^{8}$

This allocation remains high when compared to the share chosen by a Bayesian investor: the real estate weight falls to $37 \%$. Accounting for the high estimation uncertainty characterizing the relatively risky

requirement are included.

${ }^{7}$ We used other values (2 and 10), obtaining qualitatively similar results. These are available upon request from the Authors.

${ }^{8}$ For instance, Chandrashakaran [1999] finds negligible optimal weights unless the investor accounts for 
real estate and equity returns increases the share invested in T-Bills to as much as $29 \%$. In the Bayesian case, the presence of real estate equilibrates portfolio composition that is overwhelmingly invested in cash $(46 \%)$ otherwise.

Estimation risk has been found to cause substantial horizon effect in portfolio shares, when stocks and a riskless asset are considered [Barberis, 2000]. This is because the perceived (i.e., when estimation uncertainty is taken into account) variance of cumulative returns on the risky asset increases faster than linearly in the horizon T. Here we find modest horizon effects, in line with results for the i.i.d case in Fugazza et al. [2007]. For horizons of two or more years, the average share invested in real estate diminishes from 37 to $36 \%$ and the one invested in cash increases from 29 to $35 \%$

We saw that both stocks and E-REITs have high volatility and negative mean returns over the sample 1972-1976. These unfavourable initial conditions contribute to reduce average portfolio holdings of the riskier assets by investors entering the market between 1977 and 1994, which is our second recursive portfolio experiment. In Panel B of Exhibit 2 we notice that T-Bills dominate all other assets in terms of portfolio weights averaged over the longer sample 1977-2004. Without allowing for real estate the share invested in T-Bills, for both Bayesian and Classical 1-month investors, lies between 68 and 71 percent. It drops to the range $42-52$ percent when E-REITs are included. As in our shorter, main sample, real estate crowds out stock investments, the portfolio share of which falls from 20 to 5 percent, while investment in long-term bonds is almost unaffected. Despite the negative Sharpe ratio of E-REITs over the 5-year estimation period 1972-1976, the average portfolio weight of real estate turns out once more to be high, equalling $44 \%$ and $35 \%$ for a classical and a Bayesian investor, respectively. ${ }^{9}$ Thus in both sub-samples, predictable returns.

${ }^{9}$ In our experiments, E-REIT average optimal holdings exceed $30 \%$. This may turn out to be too large a share when market equilibrium is imposed. A downward revision of this weight obtains as well when considering also investments in private real estate, as in Karlberg, Liu, and Greig [1996], or in housing, 
the presence of E-REITs reduces the portfolio share invested in stocks. It also increases the overall portfolio share invested in the riskier assets (i.e., real estate, equities, and bonds) - with a corresponding reduction in the share of cash.

As one should expect, estimation risk is higher when parameter are estimated over a shorter sample. It follows that parameter uncertainty now displays larger horizon effects than in Panel A. For instance, when going from a 1-month to a 5-year horizon, a Bayesian investor reduces by $5 \%$ her portfolio share in the riskier assets and correspondingly increases investment in T-Bills.

\section{Ex Post Performance}

Expanding the asset menu cannot reduce the investor's welfare ex-ante, as it is always possible to exclude the additional asset from the optimal portfolio. Additionally, welfare can only increase in in-sample experiments. In the literature, relatively rich econometric models fitted to asset returns produce good in-sample fits and optimal portfolios built on those estimates have good in-sample performance. However, this is by no means a guarantee that expanding the asset menu will lead to improved future, ex-post portfolio performance. This problem arises, for example, when the proposed model for returns is misspecified and/or there is large parameter estimation error. To address this concern, we next explore how well real estate as an asset class performs out-of-sample.

Exhibit 3 refers to average performances over 1995-2004 when E-REITs are alternatively included or excluded from the asset menu. Panel A reveals that the mean Sharpe ratio achieved by a Classical investor falls - irrespective of the investor horizons when real estate is added to the asset menu. Such a change is substantial, a decline between 0.35 and 0.42 , for long horizons, $T=24$ and $T=60$. This is caused by the fact that ex post, realized portfolio volatility generally rises as a result of reduced investment in bonds and - above all - in cash. Such increased risk taking appears not to have been

as in De Roon et al.[2002]. 
compensated in the out-of-sample period, as mean portfolio returns fall (except for $T=1$ ) as the strategy of substituting real estate for stocks does not pay off.

However, this is not the picture emerging in the Bayesian case, reported in Panel B. Here the reduced investment in cash due to the addition of real estate to the asset menu leads to higher realized portfolio returns that offset the increase in ex-post volatility, resulting in higher mean Sharpe ratios for all investment horizons. Such gains are substantial when parameter uncertainty is accounted for: the Sharpe ratio improvement always exceeds 0.17 and reaches a stunning 0.33 for $T=6$. Thus a cautious Bayesian investor benefits ex post from increased risk taking in the form of a "switch" from equities and bonds into real estate. On the contrary, a Classical investor - who is more confident of her forecasts of future returns and fails to account for estimation uncertainty - loses from adding real estate to the available asset menu, because her pre-real estate portfolio is already considerably exposed to risk.

This heterogeneous impact of real estate on portfolio performance is not displayed by Exhibit 4, when portfolio performance is recursively computed over the longer period 1977-2004. Portfolio volatility increases in both the Classical and the Bayesian case, but mean returns also increase as investors substitute part of their overwhelming cash investments with real estate. As a consequence, the presence of real estate in the asset menu increases the ex-post Sharpe ratio, independently of whether estimation uncertainty is taken into account. ${ }^{10}$

\section{Welfare Gain Analysis}

It remains important to evaluate the effects of real estate on the expected utility of an investor. Indeed, an increase in Sharpe ratio is not necessarily associated with higher welfare, if this is obtained at the cost of

\footnotetext{
${ }^{10}$ In particular, increasing risk-taking does improve the performance for the Classical investor: in the absence of real estate, her investments in cash would massive due to the poor stock market performance of the mid-1970s.
} 
worse higher-order moment properties of portfolio returns. ${ }^{11}$ This is because investors are typically averse to negative skewness and excess kurtosis, and these preferences are fully captured by the power utility function in (1).

We therefore obtain estimates of the welfare cost of restricting the width of the asset menu available to our investors. Call $V \mathbf{W} W_{t}, \mathbf{z}_{t}$; the realized utility of the unconstrained problem - i.e., when real estate belongs to the asset menu - and $V \boldsymbol{W} W_{t}, \mathbf{z}_{t}$, the constrained realized utility, where portfolio weights obtained when real estate investments are ruled out. The compensatory premium, 疎, is defined as the percentage of wealth that when added to the investor's initial wealth, equates the realized utility from the constrained and unconstrained problems:

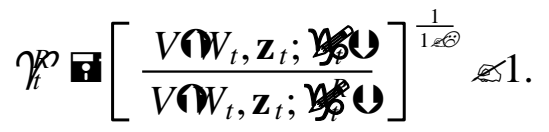

Therefore $\mathscr{K}_{t}^{R}$ is a measure of the ex-post welfare gain from enlarging the asset menu to real estate. Exhibit 4 reports our estimates of the average premium. These confirm earlier insights based on Sharpe ratios, in that they are negative for the Classical investor in 1995-2004 and positive in other cases. When positive, they are far from negligible: An investor would be willing to pay a yearly fee above $1 \%$ of her initial wealth in order to improve her portfolio performance through investments in real estate.

\section{Conclusions}

We have provided an out-of-sample analysis of portfolio performance when the asset menu alternatively excludes or includes Equity REITs. Our results confirm the conjecture that securitized real estate may considerably improve portfolio performance, be it measured via a Sharpe ratio or via realized utility, when the investor accounts for the uncertainty in her own forecasts. Adding real estate to optimal

\footnotetext{
${ }^{11}$ We know that increases in Sharpe ratios may artificially be obtained from increasing negative skewness of portfolio returns, as in Goetzman et al. [2002].
} 
portfolios usually implies higher realized volatility, which is however matched by a more-than-offsetting increase in realized mean returns. However, the increase in mean returns may sometimes be insufficient to increase the Sharpe ratio of optimal portfolios. In our sample, this happens when the investor overlooks parameter uncertainty such that her optimal portfolio composition gets massively tilted towards risky assets when securitized real estate is added to the menu. 


\section{References}

Avramov, D. (2002). Stock Return Predictability and Model Uncertainty. Journal of Financial Economics, 64, 423-458.

Ciocchetti, B., Craft, T., and Shilling, J. (2002). Institutional Investors' Preferences for REIT Stocks. Real Estate Economics, 30, 567-593.

Barberis, N. (2000). Investing for the Long Run When Returns Are Predictable. Journal of Finance, 55, $225-64$.

Bawa, V., Brown S., and Klein, R. (1979). Estimation Risk and Optimal Portfolio Choice. Amsterdam: North Holland.

Brounen, D., and Eicholtz, P. (2003). Property, Common Stock and Property Shares. Journal of Portfolio Management, Special Real Estate Issue, 129-137.

Chandrashakaran, V. (1999) The Time Series Properties and Diversification Benefits of REIT Returns. Journal of Real Estate Research, 17, 91-112.

Chun, G., Sa-Aadu, J., and Shilling, J. (2004) The Role of Real Estate in an Institutional Investor's Portfolio Revisited. Journal of Real Estate Finance and Economics, 29, 295-320.

de Roon, F., Eichholtz, P., and Koedijk, K. (2002) The Portfolio Implications of Home Ownership. CEPR discussion paper No. 3501.

Feldman, B. (2003). Investment Policy for Securitized and Direct Real Estate. Journal of Portfolio Management, Special Real Estate Issue, 112-121.

Froot, K. (1995). Hedging Portfolios with Real Assets. Journal of Portfolio Management, Summer, 60-77.

Fugazza, C., Guidolin, M., and Nicodano, G. (2007). "Investing for the Long-Run in European Real Estate", Journal of Real Estate Finance and Economics, forthcoming.

Geltner, D., and Rodriguez, J. (1995). The Similar Genetics of Public \& Private Real Estate and the Optimal Long-Horizon Portfolio Mix. Real Estate Finance, 12, 71-81

Georgiev, G., Gupta, B., and Kunkel, T. (2003). Benefits of Real Estate Investment, Journal of Portfolio Management, Special Real Estate Issue, 28-34.

Goetzmann W., Ingersoll N., Spiegel, J., and Welch, I. (2002). Sharpening Sharpe Ratios. NBER Working Paper No. 9116.

Goetzmann W., Ingersoll N., Spiegel, J., and Welch, I. (2004). Portfolio Performance Manipulation and Manipulation - Proof Performance Measures. Yale ICF Working Paper No. 02-08.

Gold, R. (1993). Why the Efficient Frontier for Real Estate is 'Fuzzy'. Journal of Real Estate Portfolio Management, 1, 59-66.

Guidolin, M., and Timmermann A. (2005). Economic Implications of Bull and Bear Regimes in UK Stock and Bond Returns. Economic Journal, 115, 111-143. 
Jobson J., Korkie, B., and Ratti, V. (1979). Improved Estimation for Markowitz Portfolios Using James-Stein Type Estimator. Proceedings of the American Statistical Association, Washington: American Statistical Association.

Jorion, P., (1985). International Portfolio Diversification with Estimation Risk. Journal of Business, 58, 259-277

Karlberg, J., Liu, C., and Greig, W. (1996). The Role of Real Estate in the Portfolio Allocation Process. Real Estate Economics, 24, 359-377.

Leland, H. (1999). Beyond Mean - Variance Performance Measurement in a Non-symmetrical World, Financial Analysts Journal, 55, 27-36.

Ling, D., Naranjo A., and Ryngaert M. (2000). The Predictability of Equity REIT Returns: Time Variation and Economic Significance. Journal of Real Estate Finance and Economics, 20, 117-136.

Liang, Y., Myer, N., and Webb, J. (1996). The Boostrap Efficient Frontier for Mixed-Asset Portfolios. Real Estate Economics, 24, 247-256.

Seiler M., Webb J., and Myer, F. (1999). Diversification Issues in Real Estate Investment, Journal of Real Estate Literature, 5, 163-179.

Ziobrowski, A., Caines, R., and Ziobrowski, B. (1999). Mixed-Asset Portfolio Composition with Long-Term Holding Periods and Uncertainty. Journal of Real Estate Portfolio Management, 2, 139-144. 


\section{Appendix}

In this section we review the solution methods for a portfolio choice problem when the horizon is long and when the uncertainty about parameter estimates may be taken into account.

\section{A1. Classical Buy-and-Hold Investor}

Call $\Sigma$ the vector collecting all the parameters, i.e. From the assumption in (5), the

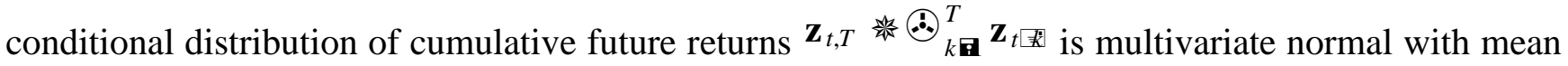
and covariance matrix given by:

$$
\begin{gathered}
E_{t-1}\left[\mathbf{z}_{t, T}\right]=T \mu \\
\operatorname{Var}_{t-1}\left[\mathbf{z}_{t, T}\right]=T \Sigma^{\prime}
\end{gathered}
$$

Since the parametric form of the predictive distribution of $\mathbf{z}_{t, T}$ is known, it is simple to approach the problem in (1), or equivalently

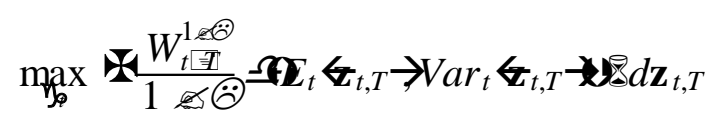

where $\mathfrak{S}_{t} \boldsymbol{女}_{t, T} \rightarrow \operatorname{Var}_{t} \mathbf{女}_{t, T} \boldsymbol{\star}$ is a multivariate normal with mean $E_{t} \boldsymbol{女}_{t, T^{-}}$and covariance matrix $\operatorname{Var}_{t} \mathbf{女}_{t, T^{-}}$, by simulation methods. This means evaluating the integral by drawing a large number of times $(N)$ from $\mathfrak{S}_{t} \boldsymbol{\sharp}_{t, T} \rightarrow \operatorname{Var}_{t} \boldsymbol{女}_{t, T} \rightarrow$ and then maximizing the functional (6). At this stage, the portfolio weight non-negativity constraints are imposed by using a simple two-stage grid search algorithm that sets $y_{q}$ to $0,0.01,0.02, \ldots, 0.99,0.9999$ for $j \boldsymbol{\nabla} s, b, r$.

\section{A2. Bayesian Buy-and-Hold Investor}

Given the problem

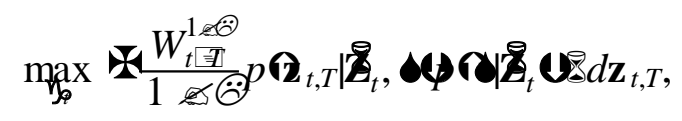


the task is somewhat simplified by the fact that predictive draws can be obtained by drawing from the posterior distribution of the parameters and then, for each set of parameters drawn, by sampling one point from the distribution of returns conditional on past data and the parameters drawn in the first stage. If we consider the following standard uninformative diffuse prior:

$$
\mathrm{p}(\mu, \Sigma) \propto|\Sigma|^{-\frac{\mathrm{n}+2}{2}}
$$

then the posterior distribution for the coefficients in $\Sigma, p\left(\mu, \Sigma^{-1} \mid \ddot{\mathbf{Z}}_{\mathrm{t}}\right)$ can be characterized as:

$$
\begin{aligned}
\Sigma^{-1} \mid \ddot{\mathbf{Z}}_{\mathrm{t}} & \sim \operatorname{Wishart}\left(\mathrm{t}-\mathrm{n}-2, \hat{\mathbf{S}}^{-1}\right) \\
\operatorname{vec}(\mu) \mid \Sigma^{-1}, \ddot{\mathbf{Z}}_{\mathrm{t}} & \sim \mathrm{N}(\operatorname{vec}(\hat{\mu}), \Sigma)
\end{aligned}
$$

where $\hat{\mathbf{S}}$ is the sample covariance of the residuals and $\hat{\mu}$ is the sample mean. Also for the Bayesian case, we adopt a simulation method by which: First, we draw $N$ independent variates from $\mathrm{p}\left(\mu, \Sigma^{-1} \mid \ddot{\mathbf{Z}}_{\mathrm{t}}\right)$. This is done by first sampling from a marginal Wishart for and then (after calculating from the conditional $\mathrm{N}(\operatorname{vec}(\hat{\mu}), \Sigma)$. Second, for each set $(\mu, \Sigma)$ obtained, the algorithm samples cumulated returns from a multivariate normal with mean vector and covariance matrix given by first-round draws. 


\section{Exhibit 1 -- Descriptive Statistics}

The left column reports descriptive statistics (mean, standard deviation and Sharpe ratio) for monthly excess returns on stocks, bonds, E-REITs and returns on cash investments (real and nominal). The sample periods considered are: January 1972 - December 1976; January 1972 - December 1994; January 1972 - November 2004. Data on stocks are from CRSP (NYSE, NASDAQ, and AMEX value-weighted indices), FREDII ${ }^{\circledR}$ Database series on 10 year Treasury bonds (constant maturity) rates of return are used for bonds, while NaREIT data are considered for Equity E-REITs. Nominal and real returns on 1 month Treasury bills are computed from FREDII ${ }^{\circledR}$ data the Consumer Price Index For All Urban Consumers (All Items, seasonally adjusted). The right panels report, for the various samples, contemporaneous correlations.

\begin{tabular}{|c|c|c|c|c|c|c|c|c|}
\hline \multicolumn{4}{|c|}{ SUMMARY STATISTISCS } & \multicolumn{5}{|c|}{ CORRELATION MATRIX } \\
\hline & Mean & St. Dev. & Sharpe Ratio & & Stock & Bond & E-REIT & Cash \\
\hline \multicolumn{9}{|c|}{ Sample: 1972:01-2004:11 } \\
\hline Stock & 0.003 & 0.046 & 0.072 & Stock & 1 & & & \\
\hline Bond & 0.001 & 0.023 & 0.054 & Bond & 0.176 & 1 & & \\
\hline E-REIT & 0.005 & 0.040 & 0.125 & E-REIT & 0.570 & 0.167 & 1 & \\
\hline Cash & 0.005 & 0.003 & & Cash & -0.069 & 0.127 & -0.104 & 1 \\
\hline Cash (Real) & 0.002 & 0.004 & & Cash (Real) & 0.120 & 0.240 & 0.074 & 0.441 \\
\hline \multicolumn{9}{|c|}{ Sample: 1972:01-1976:12 } \\
\hline Stock & -0.002 & 0.052 & -0.043 & Stock & 1 & & & \\
\hline Bond & 0.000 & 0.014 & 0.031 & Bond & 0.305 & 1 & & \\
\hline E-REIT & -0.001 & 0.051 & -0.026 & E-REIT & 0.667 & 0.290 & 1 & \\
\hline Cash & 0.005 & 0.002 & & Cash & -0.251 & 0.148 & -0.114 & 1 \\
\hline Cash (Real) & -0.001 & 0.003 & & Cash (Real) & 0.268 & 0.056 & 0.293 & 0.159 \\
\hline \multicolumn{9}{|c|}{ Sample: 1972:01-1994:12 } \\
\hline Stock & 0.002 & 0.046 & 0.050 & Stock & 1 & & & \\
\hline Bond & 0.001 & 0.023 & 0.025 & Bond & 0.305 & 1 & & \\
\hline E-REIT & 0.004 & 0.041 & 0.092 & E-REIT & 0.675 & 0.210 & 1 & \\
\hline Cash & 0.006 & 0.003 & & Cash & -0.078 & 0.189 & -0.089 & 1 \\
\hline Cash (Real) & 0.002 & 0.004 & & Cash (Real) & 0.141 & 0.304 & 0.115 & 0.474 \\
\hline
\end{tabular}




\section{Exhibit 2 -- Optimal Portfolio Weights}

This table reports mean optimal portfolio weights for stocks, bonds and cash, for the two alternative cases in which real estate is or is not in the asset menu. Means are computed over the recursive sample 1995-2004 in panel A, and over the sample 1977-2004 in panel B. The investment horizon varies from 1 to 60 months. In the Bayesian case, parameter uncertainty is accounted for. The coefficient of relative risk aversion is set equal to 5 .

\begin{tabular}{|c|c|c|c|c|c|c|c|}
\hline \multicolumn{8}{|c|}{ Panel A: 1995-2004 } \\
\hline & \multicolumn{2}{|c|}{ Stock } & \multicolumn{2}{|c|}{ Bond } & \multirow[b]{2}{*}{ E-REIT } & \multicolumn{2}{|c|}{ Cash } \\
\hline & $\begin{array}{c}\text { With } \\
\text { E-REIT }\end{array}$ & $\begin{array}{l}\text { Without } \\
\text { E-REIT }\end{array}$ & $\begin{array}{c}\text { With } \\
\text { E-REIT }\end{array}$ & $\begin{array}{l}\text { Without } \\
\text { E-REIT }\end{array}$ & & $\begin{array}{l}\text { With } \\
\text { E-REIT }\end{array}$ & $\begin{array}{l}\text { Without } \\
\text { E-REIT }\end{array}$ \\
\hline & \multicolumn{7}{|c|}{$\mathbf{T}=\mathbf{1}$} \\
\hline Classical & 0.13 & 0.40 & 0.22 & 0.25 & 0.49 & 0.16 & 0.36 \\
\hline \multirow[t]{2}{*}{ Bayesian } & 0.12 & 0.29 & 0.23 & 0.25 & 0.37 & 0.29 & 0.46 \\
\hline & \multicolumn{7}{|c|}{$\mathbf{T}=\mathbf{3}$} \\
\hline Classical & 0.13 & 0.40 & 0.22 & .25 & 0.49 & 0.16 & 0.36 \\
\hline \multirow[t]{2}{*}{ Bayesian } & 0.12 & 0.28 & 0.23 & 0.25 & 0.37 & 0.28 & 0.47 \\
\hline & \multicolumn{7}{|c|}{$T=6$} \\
\hline Classical & 0.13 & 0.40 & 0.22 & 0.25 & 0.49 & 0.16 & 0.36 \\
\hline \multirow[t]{2}{*}{ Bayesian } & 0.12 & 0.29 & 0.22 & 0.25 & 0.37 & 0.29 & 0.47 \\
\hline & \multicolumn{7}{|c|}{$\mathbf{T}=12$} \\
\hline Classical & 0.13 & 0.40 & 0.22 & 0.25 & 0.49 & 0.16 & 0.36 \\
\hline \multirow[t]{2}{*}{ Bayesian } & 0.12 & 0.29 & 0.22 & 0.25 & 0.37 & 0.30 & 0.47 \\
\hline & \multicolumn{7}{|c|}{$\mathbf{T}=\mathbf{2 4}$} \\
\hline Classical & 0.13 & 0.40 & 0.22 & 0.25 & 0.49 & 0.16 & 0.36 \\
\hline \multirow[t]{2}{*}{ Bayesian } & 0.12 & 0.29 & 0.21 & 0.24 & 0.36 & 0.31 & 0.47 \\
\hline & \multicolumn{7}{|c|}{$\mathbf{T}=60$} \\
\hline Classical & 0.13 & 0.40 & 0.22 & 0.25 & 0.49 & 0.16 & 0.36 \\
\hline Bayesian & 0.13 & 0.30 & 0.20 & 0.22 & 0.36 & 0.35 & 0.48 \\
\hline \multicolumn{8}{|c|}{ Panel B: 1977-2004 } \\
\hline & \multicolumn{7}{|c|}{$\mathbf{T}=\mathbf{1}$} \\
\hline Classical & 0.05 & 0.21 & 0.09 & 0.11 & 0.44 & 0.42 & 0.68 \\
\hline \multirow[t]{2}{*}{ Bayesian } & 0.04 & 0.20 & 0.08 & 0.09 & 0.35 & 0.52 & 0.71 \\
\hline & \multicolumn{7}{|c|}{$\mathbf{T}=\mathbf{3}$} \\
\hline Classical & 0.05 & 0.22 & 0.10 & 0.11 & 0.45 & 0.40 & 0.67 \\
\hline \multirow[t]{2}{*}{ Bayesian } & 0.04 & 0.20 & 0.08 & 0.09 & 0.35 & 0.53 & 0.71 \\
\hline & \multicolumn{7}{|c|}{$\mathrm{T}=6$} \\
\hline Classical & 0.05 & 0.22 & 0.10 & 0.11 & 0.45 & 0.40 & 0.67 \\
\hline \multirow[t]{2}{*}{ Bayesian } & 0.04 & 0.20 & 0.08 & 0.08 & 0.35 & 0.53 & 0.72 \\
\hline & \multicolumn{7}{|c|}{$T=12$} \\
\hline Classical & 0.05 & 0.22 & 0.10 & 0.11 & 0.45 & 0.40 & 0.67 \\
\hline \multirow[t]{2}{*}{ Bayesian } & 0.04 & 0.20 & 0.08 & 0.08 & 0.34 & 0.54 & 0.72 \\
\hline & & & & $\mathrm{T}=\mathbf{2 4}$ & & & \\
\hline Classical & 0.05 & 0.22 & 0.10 & 0.11 & 0.45 & 0.40 & 0.67 \\
\hline Bayesian & 0.04 & 0.20 & 0.07 & 0.09 & 0.33 & 0.56 & 0.71 \\
\hline & & & & $\mathrm{T}=60$ & & & \\
\hline Classical & 0.05 & 0.22 & 0.10 & 0.11 & 0.45 & 0.40 & 0.67 \\
\hline Bayesian & 0.04 & 0.17 & 0.07 & 0.07 & 0.32 & 0.57 & 0.75 \\
\hline
\end{tabular}




\section{Exhibit 3 - Ex-Post Performance (1995 - 2004 Sample)}

The table shows the ex post performance of optimal portfolios recursively computed over the sample January 1995 - November 2004 . Optimal portfolio weights are computed for an investor with constant relative risk aversion equal to 5 and different investment horizons (from 1 to 60 months). Two alternative asset menus are considered, with and without E-REITs. Panel A reports the performance of classical optimal portfolios while panel B covers Bayesian portfolios.

\section{Classical}

\begin{tabular}{|c|c|c|c|c|c|c|c|c|c|c|c|c|c|c|c|c|c|c|}
\hline & \multicolumn{3}{|c|}{$T=1$} & \multicolumn{3}{|c|}{$T=3$} & \multicolumn{3}{|c|}{$T=6$} & \multicolumn{3}{|c|}{$T=12$} & \multicolumn{3}{|c|}{$T=24$} & \multicolumn{3}{|c|}{$T=60$} \\
\hline & $\begin{array}{c}\text { With } \\
\text { E-REIT }\end{array}$ & $\begin{array}{l}\text { Without } \\
\text { E-REIT }\end{array}$ & $\Delta$ & $\begin{array}{c}\text { With } \\
\text { E-REIT }\end{array}$ & $\begin{array}{l}\text { Without } \\
\text { E-REIT }\end{array}$ & $\Delta$ & $\begin{array}{c}\text { With } \\
\text { E-REIT }\end{array}$ & $\begin{array}{l}\text { Without } \\
\text { E-REIT }\end{array}$ & $\Delta$ & $\begin{array}{c}\text { With } \\
\text { E-REIT }\end{array}$ & $\begin{array}{l}\text { Without } \\
\text { E-REIT }\end{array}$ & $\Delta$ & $\begin{array}{c}\text { With } \\
\text { E-REIT }\end{array}$ & $\begin{array}{l}\text { Without } \\
\text { E-REIT }\end{array}$ & $\Delta$ & $\begin{array}{c}\text { With } \\
\text { E-REIT }\end{array}$ & $\begin{array}{l}\text { Without } \\
\text { E-REIT }\end{array}$ & $\Delta$ \\
\hline Sharpe ratio & 0.389 & 0.426 & -0.037 & 0.390 & 0.425 & -0.035 & 0.397 & 0.434 & -0.037 & 0.331 & 0.492 & -0.161 & 0.196 & 0.548 & -0.351 & 0.349 & 0.772 & -0.422 \\
\hline Certainty Equivalent & 8.262 & 8.941 & -0.679 & 8.310 & 8.895 & -0.585 & 8.365 & 8.926 & -0.560 & 7.737 & 9.242 & -1.505 & 6.306 & 9.502 & -3.197 & 6.796 & 9.790 & -2.995 \\
\hline Annual Mean Returns & 10.251 & 10.240 & 0.011 & 10.007 & 10.268 & -0.261 & 9.854 & 10.116 & -0.262 & 9.469 & 10.460 & -0.991 & 8.183 & 10.780 & -2.597 & 7.156 & 10.568 & -3.412 \\
\hline Annualized Volatility & 8.353 & 6.829 & -1.524 & 7.952 & 7.091 & -0.862 & 7.741 & 6.885 & -0.857 & 8.826 & 7.278 & -1.548 & 10.022 & 8.182 & -1.840 & 4.886 & 7.994 & 3.108 \\
\hline
\end{tabular}

\section{Bayesian}

\begin{tabular}{|c|c|c|c|c|c|c|c|c|c|c|c|c|c|c|c|c|c|c|}
\hline & \multicolumn{3}{|c|}{$T=1$} & \multicolumn{3}{|c|}{$T=3$} & \multicolumn{3}{|c|}{$T=6$} & \multicolumn{3}{|c|}{$T=12$} & \multicolumn{3}{|c|}{$T=24$} & \multicolumn{3}{|c|}{$T=60$} \\
\hline & $\begin{array}{c}\text { With } \\
\text { E-REIT }\end{array}$ & $\begin{array}{l}\text { Without } \\
\text { E-REIT }\end{array}$ & $\Delta$ & $\begin{array}{c}\text { With } \\
\text { E-REIT }\end{array}$ & $\begin{array}{l}\text { Without } \\
\text { E-REIT }\end{array}$ & $\Delta$ & $\begin{array}{c}\text { With } \\
\text { E-REIT }\end{array}$ & $\begin{array}{l}\text { Without } \\
\text { E-REIT }\end{array}$ & $\Delta$ & $\begin{array}{c}\text { With } \\
\text { E-REIT }\end{array}$ & $\begin{array}{l}\text { Without } \\
\text { E-REIT }\end{array}$ & $\Delta$ & $\begin{array}{c}\text { With } \\
\text { E-REIT }\end{array}$ & $\begin{array}{l}\text { Without } \\
\text { E-REIT }\end{array}$ & $\Delta$ & $\begin{array}{c}\text { With } \\
\text { E-REIT }\end{array}$ & $\begin{array}{l}\text { Without } \\
\text { E-REIT }\end{array}$ & $\Delta$ \\
\hline Sharpe ratio & 0.310 & 0.099 & 0.211 & 0.347 & 0.023 & 0.324 & 0.352 & 0.018 & 0.334 & 0.305 & 0.027 & 0.278 & 0.200 & 0.022 & 0.178 & 0.299 & 0.037 & 0.262 \\
\hline Certainty Equivalent & 7.724 & 6.596 & 1.128 & 7.976 & 6.246 & 1.730 & 7.962 & 6.173 & 1.789 & 7.596 & 5.925 & 1.671 & 6.715 & 5.244 & 1.471 & 6.555 & 5.059 & 1.496 \\
\hline Annual Mean Returns & 8.885 & 7.286 & 1.600 & 8.978 & 6.827 & 2.151 & 8.848 & 6.748 & 2.100 & 8.578 & 6.704 & 1.874 & 7.746 & 6.510 & 1.236 & 6.839 & 6.100 & 0.739 \\
\hline Annualized Volatility & 6.439 & 5.091 & -1.348 & 6.171 & 4.777 & -1.393 & 5.993 & 4.811 & -1.182 & 6.649 & 5.727 & -0.921 & 7.468 & 7.722 & 0.255 & 4.322 & 4.100 & -0.222 \\
\hline
\end{tabular}




\section{Exhibit 4 - Ex-Post Performance (1977-2004 Sample)}

The table shows the ex post performance of optimal portfolios recursively computed over the sample January 1977 - November 2004 . Optimal portfolio weights are computed for an investor with constant relative risk aversion equal to 5 and different investment horizons (from 1 to 60 months). Two alternative asset menus are considered, with and without E-REIT. Panel A reports the performance of classical optimal portfolios while panel B covers Bayesian portfolios.

\section{Classical}

\begin{tabular}{|c|c|c|c|c|c|c|c|c|c|c|c|c|c|c|c|c|c|c|}
\hline & \multicolumn{3}{|c|}{$T=1$} & \multicolumn{3}{|c|}{$T=3$} & \multicolumn{3}{|c|}{$T=6$} & \multicolumn{3}{|c|}{$T=12$} & \multicolumn{3}{|c|}{$T=24$} & \multicolumn{3}{|c|}{$T=60$} \\
\hline & $\begin{array}{c}\text { With } \\
\text { E-REIT }\end{array}$ & $\begin{array}{l}\text { Without } \\
\text { E-REIT }\end{array}$ & $\Delta$ & $\begin{array}{c}\text { With } \\
\text { E-REIT }\end{array}$ & $\begin{array}{l}\text { Without } \\
\text { E-REIT }\end{array}$ & $\Delta$ & $\begin{array}{c}\text { With } \\
\text { E-REIT }\end{array}$ & $\begin{array}{l}\text { Without } \\
\text { E-REIT }\end{array}$ & $\Delta$ & $\begin{array}{c}\text { With } \\
\text { E-REIT }\end{array}$ & $\begin{array}{l}\text { Without } \\
\text { E-REIT }\end{array}$ & $\Delta$ & $\begin{array}{c}\text { With } \\
\text { E-REIT }\end{array}$ & $\begin{array}{l}\text { Without } \\
\text { E-REIT }\end{array}$ & $\Delta$ & $\begin{array}{c}\text { With } \\
\text { E-REIT }\end{array}$ & $\begin{array}{l}\text { Without } \\
\text { E-REIT }\end{array}$ & $\Delta$ \\
\hline Sharpe ratio & 0.470 & 0.247 & 0.223 & 0.502 & 0.335 & 0.167 & 0.518 & 0.316 & 0.203 & 0.508 & 0.353 & 0.155 & 0.488 & 0.373 & 0.115 & 0.545 & 0.439 & 0.106 \\
\hline Certainty Equivalent & 8.869 & 7.377 & 1.491 & 9.105 & 7.769 & 1.336 & 9.126 & 7.605 & 1.521 & 8.999 & 7.705 & 1.295 & 8.725 & 7.622 & 1.103 & 9.023 & 7.705 & 1.318 \\
\hline Annual Mean Returns & 10.162 & 7.923 & 2.239 & 10.367 & 8.327 & 2.040 & 10.285 & 8.148 & 2.137 & 10.251 & 8.392 & 1.859 & 10.041 & 8.645 & 1.397 & 10.094 & 8.772 & 1.322 \\
\hline Annualized Volatility & 6.736 & 4.450 & -2.287 & 6.845 & 4.562 & -2.283 & 6.723 & 4.563 & -2.161 & 7.284 & 5.216 & -2.068 & 8.195 & 6.620 & -1.574 & 10.603 & 8.845 & -1.758 \\
\hline
\end{tabular}

\section{Bayesian}

\begin{tabular}{|c|c|c|c|c|c|c|c|c|c|c|c|c|c|c|c|c|c|c|}
\hline & \multicolumn{3}{|c|}{$T=1$} & \multicolumn{3}{|c|}{$T=3$} & \multicolumn{3}{|c|}{$T=6$} & \multicolumn{3}{|c|}{$T=12$} & \multicolumn{3}{|c|}{$T=24$} & \multicolumn{3}{|c|}{$T=60$} \\
\hline & $\begin{array}{c}\text { With } \\
\text { E-REIT }\end{array}$ & $\begin{array}{l}\text { Without } \\
\text { E-REIT }\end{array}$ & $\Delta$ & $\begin{array}{c}\text { With } \\
\text { E-REIT }\end{array}$ & $\begin{array}{l}\text { Without } \\
\text { E-REIT }\end{array}$ & $\Delta$ & $\begin{array}{c}\text { With } \\
\text { E-REIT }\end{array}$ & $\begin{array}{l}\text { Without } \\
\text { E-REIT }\end{array}$ & $\Delta$ & $\begin{array}{c}\text { With } \\
\text { E-REIT }\end{array}$ & $\begin{array}{l}\text { Without } \\
\text { E-REIT }\end{array}$ & $\Delta$ & $\begin{array}{c}\text { With } \\
\text { E-REIT }\end{array}$ & $\begin{array}{l}\text { Without } \\
\text { E-REIT }\end{array}$ & $\Delta$ & $\begin{array}{c}\text { With } \\
\text { E-REIT }\end{array}$ & $\begin{array}{l}\text { Without } \\
\text { E-REIT }\end{array}$ & $\Delta$ \\
\hline Sharpe ratio & 0.512 & 0.307 & 0.205 & 0.495 & 0.323 & 0.172 & 0.532 & 0.349 & 0.182 & 0.516 & 0.353 & 0.162 & 0.485 & 0.364 & 0.121 & 0.495 & 0.450 & 0.045 \\
\hline Certainty Equivalent & 8.913 & 7.621 & 1.292 & 8.780 & 7.651 & 1.129 & 8.865 & 7.690 & 1.175 & 8.744 & 7.650 & 1.094 & 8.470 & 7.563 & 0.907 & 8.384 & 7.717 & 0.667 \\
\hline Annual Mean Returns & 9.734 & 8.055 & 1.679 & 9.581 & 8.086 & 1.495 & 9.580 & 8.110 & 1.470 & 9.528 & 8.192 & 1.336 & 9.321 & 8.365 & 0.956 & 9.188 & 8.571 & 0.617 \\
\hline Annualized Volatility & 9.734 & 8.055 & 1.679 & 9.581 & 8.086 & 1.495 & 9.580 & 8.110 & 1.470 & 9.528 & 8.192 & 1.336 & 9.321 & 8.365 & 0.956 & 9.188 & 8.571 & 0.617 \\
\hline
\end{tabular}




\section{Exhibit 5 - Welfare gains from including real estate}

The table shows the welfare gains of including real estate in the opportunity set. The welfare gains are considered through the comparison of ex-post realized utility from classical and Bayesian optimal portfolios computed for two alternative asset menus, with and without E-REIT. Optimal portfolio weights are computed for an investor with constant relative risk aversion equal to 5 and different investment horizons (from 1 to 60 months). Panel A, reports results for recursive optimal weights computed over the sample January 1995- November 2004; panel B reports results for the sample January 1977-November 2004.

\begin{tabular}{|c|c|c|c|c|c|c|}
\hline & $T=1$ & $T=3$ & $T=6$ & $T=12$ & $T=24$ & $T=60$ \\
\hline Classical & -0.624 & -0.538 & -0.514 & -1.378 & -2.919 & -2.728 \\
\hline \multicolumn{7}{|c|}{ Panel B: Sample 1977-2004 } \\
\hline Classical & 1.389 & 1.239 & 1.414 & 1.202 & 1.025 & 1.224 \\
\hline
\end{tabular}

